\title{
Chemical speciation: an instrument for evaluation of mineral bioavailability
}

\author{
Especiação química - uma ferramenta para avaliação da biodisponibilidade \\ de minerais em alimentos
}

Luana Sarpa Reis ${ }^{I}$ Édira Castello Branco de Andrade Gonçalves ${ }^{I^{*}}$

- REVIEW -

\begin{abstract}
Chemical speciation allows knowing the the different chemical forms of metals in a sample. Sequential extraction procedures are used to evaluate the fractionation of the metals in solid matrices. Few studies are described in the literature related to chemical speciation in food. Residues from fruits and vegetables generated in industry processes results in significant nutritional losses. The nutritional value of a food containing a given mineral depends not only on its content, but also on its bioavailability. The present paper emphasizes the importance of chemical speciation in food, considering the amount of loss of fruits and vegetables, since they are great sources of minerals.
\end{abstract}

Key words: chemical speciation, micronutrients, food.

RESUMO

A especiação química permite conhecer as diferentes formas químicas de minerais em uma matriz. A extração sequencial identifica as diferentes frações químicas que um metal está na amostra. Há pouco relato na literatura da aplicação da extração sequencial em alimentos. Muitos resíduos de frutas e hortaliças são gerados em processos industriais caracterizando perda nutricional significativa. $O$ valor nutricional dos minerais em um alimento está relacionado à quantidade deste e à sua biodisponibilidade. O presente estudo enfatiza a aplicação da extração sequencial em alimentos para melhor aproveitamento de resíduos de frutas e hortaliças, que são fontes de minerais.

Palavras-chave: especiação química, micronutrientes, alimentos.

\section{INTRODUCTION}

URE (1991) defined chemical speciation as "the process of identification and quantification of the different forms or phases in which one element is present in a material" or as "the description of the amounts, types of species, forms or phases present in a material "(LIMA et al., 2001). Recent studies define the chemical speciation as the individual chemical forms of an element, which together, constitute the total concentration of the element in the sample. The aim of sequential extraction method is to identify and quantify the various forms of an element in a sample (BARRA et al., 2000).

Over the past 20 years, studies of chemical speciation have been presenting great relevance, leading to the development of various methods of analysis used in the areas of health, food quality control and environment. There are many studies related to the deposition of metals in soils and waters that under reactive chemical forms, change the ecosystem and cause adverse health effects, which have attracted the attention of the scientific community (GLEYZES; TELLIER \& ASTRUC, 2002; JAIN, 2004; YAO \& GAO, 2007; GARCÍA-BARRERA et al., 2012; ).

Single and sequential extraction procedures are widely used for the investigation of soil, water, sediment, and very important, but hardly mentioned, foods, providing information on the mobility and availability of metals and other elements. Values of the total concentrations of the metals are insufficient to be evaluated, so, simple extractions can be used to estimate the fraction of the element that is potentially mobile (GLEYZES; TELLIER \& ASTRUC, 2002; BACON \& DAVIDSON, 2008; ). A single extraction reagent (usually a binder, acid or dilute salt) is used to

IPrograma de Pós-graduação em Alimentos e Nutrição (PPGAN), Universidade Federal do Estado do Rio de Janeiro (UNIRIO), Av. Pasteur, 296, Prédio Nutrição, $2^{\circ}$ andar, Urca, 22290-240, Rio de Janeiro, RJ, Brasil. E-mail: ediracba@analisedealimentos.com.br. *Corresponding author. 
treat the sample and the measurement is made on the number of elements of interest that are released from the matrix (RAO et al., 2008).

In sequential extraction, a detailed insight into the properties and behavior of the elements can be accessed. Reagents with different chemical properties are used so that the chemical forms of an element can be leached out by various mechanisms, like complexation or acidification (RAO et al., 2008; ABOLLINO, et al., 2011;). This results in a process that it is more time consuming than the simple extraction because provides a separation of the total content of an element in fractions with different bioavailability: while the first fraction is unstable and thus readily available for absorption, the last fraction is characterized by its reduced mobility (BACON \& DAVIDSON, 2008; RAO et al., 2008; ABOLLINO, et al., 2011;).

There are several factors that influence the availability of minerals: speciation, molecular bonding and the matrix. The mobility and availability of metals depend on the reactivity and behavior of chemical bonds with the components of the matrix elements, making it important to determine the accuracy and precision of each matrix studied separately (BACON \& DAVIDSON, 2008; KHOUZAM et al., 2012; RAO et al., 2008).

Chemical speciation by sequential extraction

Sequential extraction consists in the use of a number of extractors with different chemical properties that are progressively applied in a sample. Most of sequential extraction schemes include different groups of extractors: extractors with ion exchange properties; extractors with dissolution of carbonates properties; extractors with acid reducing properties; extractors that weaken the metal with organic compounds and sulfides extractors, which promote the dissolution of silicates and minerals (ANDRADE et al., 2005; RAO et al., 2008).

The growing interest in sequential extraction can be justified by the classic works of TESSIER et al. (1979). They used a five-stage extraction: five extractants to fractionate cadmium, cobalt, copper, iron, lead, nickel, manganese and zinc in river sediments containing low levels of potentially toxic elements. These stages were: metals exchange (exchangeable fraction); extractors linked to carbonates (bound to carbonate fraction); iron and manganese oxides (reducible / bound to $\mathrm{Fe}$ and $\mathrm{Mn}$ oxides / oxidic fraction); the organic compounds and sulfides (bound to organic matter / Sulfuric acid and organic) and, finally, residual extractors. The extractors were chosen based on the ability to remove specific substances, in this case, sediments.

There are still other methods in the literature about sequential extraction, which is a specific criteria used for the matrix examined, wrapped profile, metals of interest, etc. Among the procedures for sequential extraction, besides the above, one of the most used is the KERSTEN \& FORSTNER (1986) method. The difference between these two methods is the inclusion of a specific reagent for the extraction of the iron oxidic fraction. table 1 shows the different methods proposed for sequential extraction in solid matrices.

The nutritional value of a food containing a given mineral depends not only on its content, but also on its bioavailability (RUZIK, 2012). Bioavailability is a term used to indicate the proportion of elements that are absorbed and utilized by the body. The processes of absorption of micronutrients are complex and include several functions, such as osmosis, filtration, diffusion, active and selective participation and selective of the intestinal villi cells (SANTOS et al., 2004).

To understand the mechanisms involved between the chemical forms and the extractors, such as the mobility and bioavailability associated to these elements, it is necessary to know each phase corresponding to the sequential extraction.

\section{Exchangeable fraction}

This fraction includes weakly adsorbed metals retained on the solid surface by electrostatic interactions relatively weak, metals that can be released through ion exchange processes. Changes in the ionic composition influence the adsorptiondesorption reactions, or by reducing the $\mathrm{pH}$, which may cause the remobilization of metals from this fraction (KRISHNAMURTI et al., 1995; AHNSTROM \& PARKER, 2001).

The reagents used for this purpose are salts of strong acids, bases or salts of weak acids and bases, $\mathrm{pH}$ 7.0. Thus, some salts such as $\mathrm{MgCl}_{2}, \mathrm{CaCl}_{2}$, $\mathrm{KNO}_{3}$ or $\mathrm{NH}_{4} \mathrm{OAc}$, are normally chosen to extract metals, for displacement of the adsorption sites (URE \& DAVIDSON, 2001). These reagents do not attack organic matter, silicates and metal sulfides, but can dissolve carbonates, except when the extraction time is short (GLEYZES et al., 2002).

The most popular is the extractor $\mathrm{MgCl} 2$ $1 \mathrm{~mol} \mathrm{l}{ }^{-1}$, which combines the high capacity of $\mathrm{Mg}^{+2}$ with the weak complexation of $\mathrm{Cl}^{-}$. However, $\mathrm{Ca}^{2+}$ has been the most effective at removing $\mathrm{Mg}^{2+}$ ions related to exchangeable fraction (GLEYZES et al., 2002). 
Table 1 - Extractors for solid matrices.

\begin{tabular}{|c|c|c|}
\hline Fration & Extractor & References \\
\hline \multirow{4}{*}{ Exchangeable } & $\mathrm{MgCl}_{2}$ & TESSIER et al. (1979) \\
\hline & $\mathrm{NH}_{4} \mathrm{Ac} / \mathrm{CaCl}_{2}$ & KERSTEN \& FORSTNER (1986) / HIRNER et al. (1990) \\
\hline & $\mathrm{KNO}_{3}$ & MILLER \& MCFEE (1983) / SPOSITO et al. (1982) \\
\hline & $\mathrm{Mg}\left(\mathrm{NO}_{3}\right)_{2}$ & SHUMAN \& HARGROVE (1985) \\
\hline \multirow{4}{*}{ Carbonates } & $\mathrm{NaOAc}$ e HAc & TESSIER ET AL. (1979) \\
\hline & NaAc e HAc & KERSTEN \& FORSTNER (1986) \\
\hline & EDTA & MILLER \& MCFEE (1983) \\
\hline & $\mathrm{HNO}_{3}$ & SPOSITO et al. (1982) \\
\hline \multirow{6}{*}{ Oxidic / oxides (Fe e Mn oxides) } & $\mathrm{NH}_{2} \mathrm{OH} . \mathrm{HCl}$ e $\mathrm{HAc}(\mathrm{Fe}$ e $\mathrm{Mn})$ & TESSIER ET AL. (1979) / SHUMAN \& HARGROVE (1985) \\
\hline & $\mathrm{NH}_{2} \mathrm{OH} . \mathrm{HCl}$ e $\mathrm{HNO}_{3}(\mathrm{Mn})$ & $\begin{array}{l}\text { KERSTEN E FORSTNER (1986) / MILLER \& MCFEE } \\
(1983)\end{array}$ \\
\hline & Tampão de oxalato (Fe) & KERSTEN \& FORSTNER (1986) \\
\hline & $\mathrm{NaHCO}_{3}$ e $\mathrm{N}_{2} \mathrm{~S}_{2} \mathrm{O}_{4}$ (Fe cristalino) & MILLER \& MCFEE (1983) \\
\hline & $\left(\mathrm{NH}_{4}\right)_{2} \mathrm{O}_{\mathrm{x}}(\mathrm{Fe})$ & SHUMAN \& HARGROVE (1985) \\
\hline & $\begin{array}{l}\text { Tampão de Oxalato e Ácido Ascóbico } \\
\text { (Fe cristalino) }\end{array}$ & Shuman \& Hargr\&ove (1985) \\
\hline \multirow{5}{*}{ Organic } & $\mathrm{H}_{2} \mathrm{O}_{2} / \mathrm{HNO}_{3} / \mathrm{NH}_{4} \mathrm{Ac}$ & TESSIER ET AL.(1979) / KERSTEN \& FORSTNER (1986) \\
\hline & $\mathrm{Na}_{4} \mathrm{P}_{2} \mathrm{O}_{7}$ & MILLER \& MCFEE (1983) \\
\hline & $\mathrm{NaOCl}$ & SHUMAN \& HARGROVE (1985) \\
\hline & EDTA & SPOSITO et al. (1982) \\
\hline & $\mathrm{C}_{6} \mathrm{H}_{6} / \mathrm{CH}_{3} \mathrm{OH}$ & HIRNER et al. (1990) \\
\hline \multirow{2}{*}{ Sulfides } & $\mathrm{H}_{2} \mathrm{O}_{2} / \mathrm{HNO}_{3} / \mathrm{NH}_{4} \mathrm{Ac}$ & TESSIER et al. (1979) / KERSTEN \& FORSTNER (1986) \\
\hline & $\mathrm{HNO}_{3}$ & MILLER \& MCFEE (1983) / SPOSITO et al. (1982) \\
\hline \multirow{4}{*}{ Residual } & $\mathrm{HF}$ e $\mathrm{HClO}_{4}$ & TESSIER ET AL. (1979) / KERSTEN \& FORSTNER (1986) \\
\hline & $\mathrm{HF} / \mathrm{HClO}_{4} / \mathrm{HNO}_{3}$ & KERSTEN \& FORSTNER (1986) \\
\hline & $\mathrm{HNO}_{3} / \mathrm{H}_{2} \mathrm{O}_{2}$ & MILLER \& MCFEE (1983) \\
\hline & $\mathrm{HCl} / \mathrm{HF} / \mathrm{HNO}_{3}$ & SCHUMAN \& HARGROVE (1985) \\
\hline Water-solubles & $\mathrm{H}_{2} \mathrm{O}$ & MILLER \& MCFEE (1983) / HIRNER et al. (1990) \\
\hline Humics & $\mathrm{C}_{6} \mathrm{H}_{6} / \mathrm{CH}_{3} \mathrm{OH} / \mathrm{KOH}$ & HIRNER et al. (1990) \\
\hline Insoluble organic & $\mathrm{HCl} / \mathrm{HClO}_{4} / \mathrm{HNO}_{3}$ & Hirner et al. (1990) \\
\hline
\end{tabular}

Adapted from DAS et al. (1995).

Bound to carbonates / Soluble fraction in acid

This fraction is bound by covalent forces, and therefore there is no easy displacement of metal as in the previous fraction. The metals are precipitated or co-precipitated with carbonates, which can be an important adsorbent for many metals when the organic matter and the oxides of iron and manganese are less abundant (RAO et al., 2008).

This phase is susceptible to changes in $\mathrm{pH}$ by the use of a moderate acid. The use of solutions buffered at $\mathrm{pH} 5.0$ have long been used at this stage, for example, the buffer acetic acid / sodium acetate or acetic acid / ammonium acetate at $\mathrm{pH} 5.0$ allowing the release occurrence of organic and inorganic metal substrates (AHNSTROM \& PARKER, 2001; LI et al., 2001).

The reduction of $\mathrm{pH} 7.0$ (the exchangeable phase) to $\mathrm{pH} 5.0$ at this stage allows release of the remaining adsorbed ions, more specifically, trace elements which were not extracted in the previous fraction. High proportions of manganese are found in the extracts of acetic acid / sodium acetate (TESSIER et al., 1979). 
Reducible / bound to $\mathrm{Fe}$ and $\mathrm{Mn}$ oxides / oxidic fraction

The reducible fraction or also called oxidic dissolve oxides and hydroxides of iron and manganese. The extraction of these secondary oxides present superficial layers of minerals as well as discrete particles or may occur by the following mechanisms or combination thereof: adsorption; ion exchange; complex formation surface; co-precipitation and penetration crystal lattice (HALL et al., 1996).

The reducible fraction may be divided into three: fraction easily reducible (manganese oxides), moderately reducible fraction (amorphous oxides of iron); and poorly reducible fraction (crystalline iron oxides). This classification is discussed in some sequential extraction schemes (KRISHNAMURTI et al., 1995). The control of the reduction potential and the $\mathrm{pH}$ of this fraction can dissolve reagents in some or all of the phases of oxides and hydroxides of iron and manganese (GLEYZES et al., 2002).

Bound to organic matter / Sulfuric acid and organic fraction

In this fraction occurs organic matter degradation in oxidizing conditions leading to a release of soluble metals associated with these components. The metals bound to sulfides can also be extracted during this phase (MARIN et al., 1997). The most common oxidants are hydrogen peroxide in moderate acid, $\mathrm{NaOCl}$ in $\mathrm{pH}=9,5, \mathrm{Na}_{4} \mathrm{P}_{2} \mathrm{O}_{7}$ in $\mathrm{pH}=9,5$ and $\mathrm{K}_{4} \mathrm{P}_{2} \mathrm{O}_{7}$. In general, hydrogen peroxide heated is more used to dissolve the organic matter, because it causes an effective attack therein and produces minimal change in silicates. Perhaps the most important disadvantage of this reagent is supplied by the resorption of metals in the residual fraction, which requires an additional extraction with ammonium acetate at $\mathrm{pH}$ $=2$ (SUTHERLAND et al., 2000; FERREIRA \& SANTANA, 2012).

The combination $\mathrm{H}_{2} \mathrm{O}_{2} / \mathrm{NH}_{4} \mathrm{OAc}$, where the addition of $\mathrm{NH}_{4} \mathrm{OAc}$ prevents resorption of the extracted metals, has been adopted in many schemes for extracting metals associated with organic matter and sulfides (KRISHNAMURTI et al., 1995).

\section{Residual fraction}

The extraction of this metal fraction occurs by digestion with strong acids such as $\mathrm{HF}, \mathrm{HClO}_{4}$, $\mathrm{HCl}$ and $\mathrm{HNO}_{3}$. The amount of metals associated with this fraction is also reported by some authors as the difference between the total concentration and the sum of all fractions of metals extracted during the previous steps (CHLOPECKA et al., 1996).
Several reagents used in sequential extraction procedures have advantages and disadvantages and there is not a reactant or ideal protocol for general use in the case of food. Therefore, the selection process must be related to a defined objective, taking into account the nature of the sample (RUZIK, 2012). Note that, after the choice of the sequential extraction procedure, only soluble species can be extracted, which reproduce the conditions of bioavailability of each element (BOUYSSIERE et al., 2003).

\section{Sequential extraction in food matrices}

The verification of the concentrations of trace toxic and those considered essential nutrients in food elements is performed in many countries. In the last two decades has been shown that food safety and nutritional quality of foods also depend on the chemical form in which an element is present therein, since the bioavailability, activity, and toxicity of beneficial minerals are a function of metal concentration, its oxidation state and the chemical form in which it is found in the sample (EBDON et al., 2001).

The number of studies on chemical speciation in food has increased significantly and reached a rate of ninety articles per year, but only a few elements are widely studied (such as arsenic, selenium and mercury), while others do not attract the attention of researchers. Elements such as Co, I, $\mathrm{Mn}, \mathrm{Fe}, \mathrm{Zn}, \mathrm{Cu}$ and $\mathrm{Mo}$ have received little attention so far because of their low concentrations in foods, complex instability and chemical behavior of the species, making it a challenge for the chemistry (RUZIK, 2012).

Analysis by sequential extraction in food should provide some care, since each has a different foodstuff and chemical matrix requires a special control interference. The complex of minerals that are formed with nutrients in foods, especially those formed with labile metal matrix lose their stability with the change of state of oxidation, hydrolysis, methylation and the action of microorganisms (RAYMAN, 2004; SCHRAUZER, 2006).

The sequential extraction should be performed to separate the matrix elements without loss and without altering the original forms, however, extraction from solid samples that do not generate losses or contamination and no changes to the species are extremely difficult. It must have adequate recovery of these samples (attack with strong acid) and preservation of the species (QUEVAUVILLER et al., 1996).

The choice of technique for extraction should have some considerations: the chemical 
properties of the substances to be analyzed, their chemical forms, the matrix and the application technique (RUZIK, 2012). Depending on the matrix of the sample to be analyzed, and the elements of interest, extracting, dissolving, leaching or solid-liquid extraction may be performed for the isolation of species, since the procedure preserves it (BOUYSSIERE et al., 2003).

ANDRADE et al. (2005) analyzed samples of vegetables types A and B for total zinc content by atomic absorption spectrometry in flame (FAAS), and the method of sequential extraction was applied with the following extractors: $1 \mathrm{M}$ calcium chloride, $0.1 \mathrm{M}$ acetic acid / 5\% ammonium acetate ( $\mathrm{pH} 5.0$ ), $0.5 \mathrm{M}$ acetic acid, 0.5 hydrochloric acid. At least six different chemical species for zinc were found in these samples.

SILVA et al. (2010) evaluated the total content and bioavailability of iron, manganese and zinc in extracts of the peels and leaves of Caesalpinia ferrea Martius also using FAAS. The extractors used in the sequential extraction were: $0.05 \mathrm{MNaOH}, 0.05 \mathrm{M}$ Tris- $\mathrm{HCl}(\mathrm{pH}=8), 1 \%(\mathrm{w} / \mathrm{v})$ sodium dodecyl sulfate (SDS), $0.05 \mathrm{M} \mathrm{HCl}$ and hot water $\left(60^{\circ} \mathrm{C}\right)$. The peel of the fruit and the leaves showed high levels of iron and manganese. Iron showed better bioavailability in the peel and leaves of the fruit. Manganese and zinc were more potentially bioavailable in the leaves.

GONÇALVES \& TAKASE (2005) evaluated the sequential extraction of copper and zinc in vegetables type $\mathrm{C}$, using FAAS. The extractors used were: $1 \mathrm{M} \mathrm{MgCl}, \mathrm{pH}=7.0 ; 0.5 \mathrm{M}$ acetic acid / 5\% ammonium acetate $(\mathrm{pH} 5.0) ; 1 \mathrm{M}$ acetic acid; $0.1 \mathrm{M}$ sodium hidroxyde and $0.5 \mathrm{M} \mathrm{HCl}$. It was observed that copper was presented in at least three different chemical species and the zinc was extracted with efficacy in the majority of samples studied with four extractors.

There are few studies related to chemical speciation in food and it is of interested to expand these analyzes to this area, since the speciation of metals is already recognized in biological and environmental analysis (DAS et al., 1995). In this way, information about chemical speciation in food is extremely important for studies of human nutrition and health (KHOUZAM et al., 2012).

Considering that chemical speciation allows to separate compounds by their different chemical characteristics, this technique is a useful tool for assessing the bioavailability of minerals in foods. The chemical interactions that minerals have in a food are likely to identification by this technique. The exchangeable fraction by extracting the weakly adsorbed in the matrix metal, released by ionic exchange, most likely identifies the metals as salts. The bound to carbonate fraction represents the fraction of the chemical compounds in the matrix interaction that involves covalent forces as well as changes in $\mathrm{pH}$, promotes the extraction of metals strongly bound to the matrix, probably intermolecular interactions. The oxidic fraction causes degradation of organic matter, possibly featuring the metals with intramolecular interaction with the macronutrients. These chemical influence the specificity, single or facilitated absorption occurring during the diffusion process, affecting the bioavailability of the metal.

\section{CONCLUSION}

The chemical speciation in some micronutrients and trace elements in food is important to human health, but it is a challenge to researchers and also to the chemistry. Low concentrations of these elements in food, complex chemical behavior and instability of the species are the reasons why there are not many studies in this area. As the food matrix and sequential extraction procedures in foods are very varied, it is possible to observe the diversity of chemical interactions between species.

It is known that there is no general protocol for sequential extraction in foods and therefore it should be always take into consideration the nature of the sample. Mechanisms of sequential extraction in foods should be stimulated to provide a better understanding of metal speciation into the matrix as well as mobility and bioavailability.

\section{REFERENCES}

ABOLlinO, O. et al. The role of chemometrics in single and sequential extraction assays: a review: Part I. Extraction procedures, uni-and bivariate techniques and multivariate variable reduction techniques for pattern recognition. Analytica Chimica Acta, Netherlands, v.688, n.2, p.104-121, Jan., 2011. Available from: $<$ http://www.ncbi.nlm.nih.gov/pubmed/21334476>. Accessed: Nov. 19, 2013. doi: 10.1016/j.aca.2010.12.020.

AHNSTROM, Z.A.S.; PARKER, D.R. Cadmium reactivity in metal-contaminated soils using a coupled stable isotope dilution-sequential extraction procedure. Environmental Science \& Technology, United States, v.35, n.1, p.121-126, Nov., 2001. Available from: <http://www.ncbi.nlm.nih.gov/ pubmed/11351995>. Accessed: Nov. 19, 2013. doi: 10.1021/ es001350o.

ANDRADE, E.C.B. et al. Determinação dos teores de zinco em diferentes extratos de hortaliças dos tipos A e B. Ciência e Tecnologia de Alimentos, Campinas, v.25, n.2, p.591-596, Apr./Jun., 2005. Available from: <http://www.scielo.br/pdf/cta/ v25n2/25022>. Accessed: Nov. 19, 2013. doi: 10.1590/S010120612005000200014. 
BACON, J.R.; DAVIDSON, C.M. Is there a future for sequential chemical extraction? Analyst, United Kingdom, v.133, p.2546, Sept., 2008. Available from: <http://pubs.rsc.org/en/content/ articlelanding/2008/an/b711896a\#!divAbstract $>$. Accessed: Nov. 19, 2013. doi: $10.4236 /$ fns.2013.48A024.

BARRA, C.M. et al. Especiação de arsênio - Uma revisão. Química Nova, São Paulo, v.23, p.58-70, Apr., 2000. Available from: <http://www.scielo.br/pdf/qn/v23n1/2145.pdf >. Accessed: Nov. 19, 2013. Doi: 10.1590/S0100-40422000000100012.

BOUYSSIERE, B. et al. (Ed.). Sample preparation tyechniques for elemental speciation studies. In: Handbook of elemental speciation: techniques and methodology. John Wilwy \& Sons, Ltd. Chichester, England, p. 95-118, 2003. Available from: $<$ http:// onlinelibrary.wiley.com/doi/10.1002/0470868384.fmatter/pdf $>$. Accessed: Nov. 19, 2013. doi: 10.1002/0470868384.ch4.

CHLOPECKA, A. et al. Forms of cadmium, lead, and zinc in contaminated soils from southwest Poland. Journal of Environmental Quality, Madison, v.25, n.1, p.69-79, Jan. 1996. Available from: <http://openagricola.nal.usda.gov/Record/ IND20581448>. Accessed: Nov. 21, 2013. doi: 10.2134/jeq1996. 00472425002500010009x

DAS, K.B. et al. Metal speciation in solid matrices. Talanta Netherlands, v.42, n.8, p.1007-1030, Feb., 1995. Available from: $<$ http://www.ncbi.nlm.nih.gov/pubmed/18966324>. Accessed: Nov. 19, 2013. doi: 10.1016/0039-9140(95)01557-R.

EBDON, L. et al. Trace element speciation for environment, food and health. Quevauvilier: Royal Society of Chemistry, 360 p. 2001. Available from: <http://pubs.rsc.org/en/Content eBook/978-0-85404-459-7\#!divbookcontent>. Accessed: Nov. 19, 2013. doi: $10.1039 / 9781847552204$.

FERREIRA，P.R.G.; SANTANA， G.P. Tratamento químico seletivo: uma especiação operacional. Scientia Amazonia Manaus, v.1, n.3, p.40-48, Nov., 2012. Available from: $<$ http:// www.scientia.ufam.edu.br/attachments/article/16/v.1\%20n.3,\%20 40-48,\%202012.pdf>. Accessed: Nov. 21, 2013. doi: 2238.1910.

GARCÍA-BARRERA, T. et al. Biological responses related to agonistic, antagonistic and synergistic interactions of chemical species. Analytical and Bioanalytical Chemistry, Germany, v.403, p.2237-2253, Feb., 2012. Available from: <http://www. ncbi.nlm.nih.gov/pubmed/22367285>. Accessed: Nov. 19, 2013. doi: 10.1007/s00216-012-5776-2.

GLEYZES, C. et al. Fractionation studies of trace elements in contaminated soils and sediments: a review of sequential extraction procedures. Trends in Analytical Chemistry, Netherlands, v.21, n.6, p.451-467, June, 2002. Available from: <http://www.sciencedirect.com/science/article/pii/ S0165993602006039>. Accessed: Nov. 19, 2013. doi :10.1016/ S0165-9936(02)00603-9.

GONÇALVES, E.C.B.A.; TAKASE, I. Determinação dos teores de cobre em diferentes extratos de hortaliças do tipo A e B. Ciênc. Tecnol. Aliment. vol.24 no.2 Campinas Apr./June 2004. Available from: $\quad<\mathrm{http}: / /$ www.scielo.br/scielo.php?pid=S010120612004000200020\&script=sci_arttext>. Accessed: Nov. 19, 2013. doi: 10.1590/S0101-2061200400020002.

HALL, A.C. et al. Intestinal metallothionein and the mutual antagonism between copper and zinc in the rat. Journal of inorganic biochemistry, United States, v.11, p.57-66, 1979. Available from: <http://www.ncbi.nlm.nih.gov/pubmed/479878>. Accessed: Nov. 19, 2013. doi: 10.1016/S0162-0134(00)80054-9.

JAIN, C.K. Metal fractionation study on bed sediments of River Yamuna, India. Water Research, United States, v.38, n.3, p.569578, Oct., 2004. Available from: $<$ http://www.sciencedirect.com/ science/article/pii/S0043135403006213>. Accessed: Nov. 19, 2013. doi: $10.1007 / \mathrm{BF} 00398602$.

KERSTEN, M.; FORSTNER, U. Chemical fractionation of heavy metals in anoxic estuarine and coastal sediments. Water Science Technology, Poland, v.18, p.121-130, 1986. Available from: $<$ http://www.iwaponline.com/wst/01804/wst018040121.htm>. Accessed: Nov. 19, 2013. doi: 0273-1223/86.

KHOUZAM, R.B. et al. Trace element speciation in food: State of the art of analytical techniques and methods. Pure Applied Chemistry, United States, v.84, n.2, p.169-179, Jan., 2012. Available from: $<$ http://www.iupac.org/publications/pac/84/2/0169/>. Accessed: Nov. 19, 2013. doi: 10.1351/PAC-CON-11-08-14.

KRISHNAMURTI, G.S.R. et al. A new soil test method for the determination of plant-available cadmium in soils. Communications in Soil Science \& Plant Analysis, United Kigdom, v.16, n.17-18, p.2857-2867, Nov., 1995. Available from: <http://www.tandfonline.com/doi/ abs/10.1080/00103629509369493\#.Uowwo8SThqU>. Accessed: Nov. 19, 2013. doi: 10.1080/00103629509369493.

$\mathrm{LI}$, X. et al. Chemical forms of $\mathrm{Pb}, \mathrm{Zn}$ and $\mathrm{Cu}$ in the sediment profiles of the Pearl River Estuary. Marine Pollution Bulletin, Netherlands, v.42, n.3, p.215-223, Mar., 2001. Available from: $<$ http://www.ncbi.nlm.nih.gov/pubmed/11381876>. Accessed: Nov. 19, 2013. doi: 10.1016/S0025-326X(00)00145-4.

LIMA, M.C. et al. Especiação de cobre e chumbo em sedimento do rio tubarão (SC) pelo método Tessier. Química Nova, São Paulo, v.24, p.734-742, Nov., 2001. Available from: $<$ http://www. scielo.br/pdf/qn/v24n6/6777.pdf>. Accessed: Nov. 19, 2013. doi: 10.1590/S0100-40422001000600005.

MARIN, B. et al. Reproducibility testing of a sequential extraction scheme for the determination of trace metal speciation in a marine reference sediment by inductively coupled plasmamass spectrometry. Analytica Chimica Acta, Netherlands, v.342, n.2, p.91-112, Apr., 1997. Available from: <http://www. ingentaconnect.com/content/els/00032670/1997/00000342/00000 002/art00580>. Accessed: Nov. 19, 2013. doi: 10.1016/S00032670(96)00580-6

QUEVAUVILLER, P. et al. Quality control of results of speciation analysis. In: CAROLI, S. Element speciation in bioinorganic chemistry. New York: Wiley, 1996. p.195-222. Available from: <http:// www.wiley.com/WileyCDA/WileyTitle/productCd-0471576417. html>. Accessed: Nov., 19, 2013. doi: 978-0-471-57641-9.

RAO, C.R.M. et al. A review of the different methods applied in environmental geochemistry for single and sequential extraction of trace elements in soils and related materials. Water Air \& Soil Pollution, Germany, v.189, p.291-333, Jan., 2008. Available from: <http:// link.springer.com/article/10.1007\%2Fs11270-007-9564-0\#page-1>. Accessed: Nov. 19, 2013. doi: 10.1007/s11270-007-9564-0.

RAYMAN, M.P. The use of high-selenium yeast to raise selenium status: how does it measure up? British Journal of Nutrition, 
United States, v.92, n.4, p.557-574, Jun., 2004. Available from: $<$ http://www.ncbi.nlm.nih.gov/pubmed/15522125>. $\quad$ Accessed: Nov. 21, 2013. Doi: 10.1079/BJN20041251

RUZIK, L. Speciation of challenging elements in food by atomic spectrometry. Talanta, Netherlands, v.93, p.18-31, Feb., 2012. Available from: $<$ http://www.sciencedirect.com/science/article/pii/ S0039914012001075>. Accessed: Nov. 19, 2013. doi: 10.1016/j. talanta.2012.01.066.

SANTOS, H.B. et al. Estudos bioquímicos e hematológicos em ratos sobre biodisponibilidade de minerais numa dieta enriquecida com multimistura. Ciência e Tecnologia de Alimentos, Campinas, v.24, n.4, p.613-618, Oct./Dec., 2004. Available from: $<$ http://www.scielo.br/scielo.php?script=sci_arttext\&pid=S010120612004000400023\&lng=en\&nrm=iso $>$. Accessed: Oct. 07, 2014. doi: 10.1590/S0101-20612004000400023.

SCHRAUZER, G.N. Selenium yeast: composition, quality, analysis, and safety. Pure and Applied Chemistry, United States, v.78, p.105-109, Oct., 2006. Available from: <http://pac.iupac.org/ publications/pac/pdf/2006/pdf/7801x0105.pdf $>$. Accessed: Nov. 21, 2013. doi: $10.1351 /$ pac200678010105

SILVA, C.S. et al. Avaliação do uso da casca do fruto e das folhas de Caesalpinia ferrea Martius como suplemento nutricional de $\mathrm{Fe}, \mathrm{Mn}$ e $\mathrm{Zn}$. Ciência e Tecnologia de Alimentos, Campinas, v.30, n.3, p.751-754, Jul./Sept., 2010. Available from: <http://www.scielo.br/pdf/cta/v30n3/ v30n3a28.pdf $>$. Accessed: Nov. 21, 2013. doi: 10.1590/ S0101-20612010000300028.
SUTHERLAND, R.A. et al. Operationally defined metal fractions in road deposited sediment, Honolulu, Hawaii. Journal of Environmental Quality, Madison, v.29, n.5, p.1431-1439, Oct., 2000. Available from: <https://dl.sciencesocieties.org/ publications/jeq/abstracts/29/5/JEQ0290051431 access $=0 \& v i e w=$ pdf $>$. Accessed: Nov. 21, 2013. doi: 10.2134/jeq2000.0047242 5002900050009x.

TESSIER, A. et al. Sequential extraction procedure for the speciation of particulate trace metals. Analytical chemistry, United States, v.51, n.7, p.844-851, Jun., 1979. Available from: $<$ http://pubs.acs.org/doi/abs/10.1021/ac50043a017>. Accessed: Nov. 19, 2013. doi: 10.1021/ac50043a017.

URE, A.M. Trace element speciation in soils, soil extracts and solutions. Microchimica Acta, Austria, v.104, p.49-57, 1991. Available from: <http://link.springer.com/article/10.1007\%2FB F01245495\#page-1>. Accessed: Nov. 19, 2013. doi: 10.1007/ BF01245495 pp.49-57.

URE, A.M.; DAVIDSON, C.M. Chemical Speciation in the Environment. 2.ed. Glasgow: University of Strathdyde, Blackwell Science, 480 p. 2001. Available from: <http://onlinelibrary.wiley. com/book/10.1002/9780470988312>. Acessed, Nov., 19, 2013. doi: $10.1002 / 9780470988312$.

YAO, Z.; GAO, P. Heavy metal research in lacustrine sediment: a review. Chinese Journal of Oceanology and Limnology, China, v.25, n.4, p.444-454, Oct., 2007. Available from: <http://link. springer.com/article/10.1007\%2Fs00343-007-0444-7\#page-1>. Accessed: Nov. 19, 2013. doi: 10.1007/s00343-007-0444-7. 